\title{
Political Efficacy and Community Well-being of the Residents in Davao City, Philippines
}

\author{
Rico B. Maghuyop, Ed. D. ${ }^{1}$, Melanie R. Bonita ${ }^{2}$, Alily Grace M. Sardeñola ${ }^{2} \&$ Ivanne M. Lumain $^{2}$ \\ ${ }^{1}$ Social Science Discipline, University of Mindanao, Davao City, Philippines \\ ${ }^{2}$ Political Science Program, University of Mindanao, Davao City, Philippines \\ Correspondence: Rico B. Maghuyop, Ed. D., Social Science Discipline, University of Mindanao, Davao City, \\ Philippines.
}

Received: June 23, 2015

Accepted: July 8, 2015

Available online: August 6, 2015

doi:10.11114/ijsss.v3i5.1011

URL: http://dx.doi.org/10.11114/ijsss.v3i5.1011

\begin{abstract}
Recently, community well-being had been the new trend in identifying good governance and progress of certain areas. It can be affected by different factors and highly reflects not only well-being of the people living in the community but also the performance of the local government unit in the area as perceived by the citizens. The research trust of this study was to determine the level of political efficacy and community well-being of the residents in Davao City, Philippines. Using descriptive correlational method, results of the study revealed a high level of political efficacy contributed by internal and external efficacy of the residents. While the other findings of the study revealed high level of community well-being with respect to healthy, safe and inclusive community; culturally rich and vibrant community; dynamic resilient community; and sustainable and democratic environment. Also, the study further revealed a significant relationship between political efficacy and community well-being which implies that the feeling of an individual towards his or her political action affects the political system and the perception of the living conditions of the residents in the area.
\end{abstract}

Keywords: Political efficacy; Community well-being; Davao City, Philippines.

\section{Introduction}

Throughout the world, it has been the prime duty of the government to secure and maximize the well-being of its citizen (O'Donnell, Deaton, Durand, Halpern, \& Layard, 2014). In economics, measuring well-being has been the center of prominence in determining and achieving greater progress (Anderson, Cooper, Layard, Litchfield, \& Jane-Llopis, 2012). In fact, it was discovered in Taiwan that life satisfaction of the people is investigated based on two aspects namely people's personal life and their perceived condition of living. Through these two aspects which initially reflect both personal and national well-beings; Taiwanese people are considered to be moderately happy within their own boundaries (Ip and Cheung, 2014). On the other hand, Africa which is known to be the poorest continent in the world is currently facing a challenge on improving their well-being. One factor which is espoused as an instrument in improving well-being is social capital which takes in trust with the government to be a potent force to achieve economic growth in some African regions (Ddai, Opoku-agyeman and Ghartey, 2013).

Meanwhile in the Philippine context, well-being is measured through the Philippine Happiness Index (PHI) by the National Statistical Coordinating Board (NSCB). They used 20 indicators such as work, economy, friends, sex- life, religion, and community participation including volunteer works in measuring the happiness index among Filipinos (Ubalde, 2012). Based on the 2007, 2008, and 2010 study on PHI, it was found out that most of the respondents think that progress is synonymous with happiness and gender difference which is a variable that determines the well-being of an individual (Virola, Encarnacion, Pascasio, \& Clavido, 2010). Also, it was found out that the most important source of happiness among the Filipinos is their family (Virola, 2010).

On the other hand, Mangahas (2014) stated that it was the first time for Davao City to have a social poll covering topics pertaining to politics and its life in the city. In fact, most of the respondents are satisfied with the city government particularly with Mayor Rodrigo Duterte's administration despite the specific threats to peace and order that threaten the citizens' well-being of the city. Generally, the respondents consider themselves happy living in the city. 
It is in this context that the researchers are impelled to conduct a study to find out if the political efficacy has a significant relationship on measuring the level of community well-being of the residents in Davao City. Further the result of the study could be a source of reference for Davao City to enhance their community well-being and more importantly a supplementary foundation for future policy formation bringing this study a record with ample social significance.

\subsection{Statement of the Problem}

The thrust of this study was to find out the relationship between political efficacy and community well-being of the residents in Davao City. More specifically, this study endeavoured to determine the following objectives:

1.1.1 To determine the level of political efficacy of the residents in Davao City in terms of:

\subsubsection{Internal efficacy}

\subsubsection{External efficacy.}

1.1.2 To determine the level of community well-being of the residents in Davao City in terms of:

1.1.2.1 Healthy, safe and inclusive community

1.1.2.2 Culturally rich and vibrant community

\subsubsection{Dynamic resilient community}

\subsubsection{Sustainable and democratic environment.}

1.1.3 To determine the significant relationship between political efficacy and community well-being of the residents in Davao City.

\subsection{Hypothesis}

The null hypotheses will be tested at 0.05 level of confidence.

There is no significant relationship between the political efficacy and community well-being of the residents in Davao City.

\section{Research Methodology}

This study made use of non-experimental quantitative research design utilizing descriptive-correlation technique. This study is non-experimental research because the independent variables of the study are not manipulated and are not randomly assigned to groups (Johnson and Christensen, 2000). The data of this study also describes the barangays' level of political efficacy as well as the level of community well-being of the residents of selected barangay. Furthermore, the study is correlational because the study has determined whether the single independent and the single dependent variable have a significant relationship with each other. The respondents of this study are the one hundred fifty residents of Davao City, Philippines.

\subsection{Measures}

The instrument used in this study consisted of two parts. Part 1 dealt with the residentslevel of political efficacy which focuses highly to the two identified indicators: Internal Efficacy and External Efficacy. The said instrument is patterned and modified based on the questionnaire developed by Xiaoyi Hu (2011). Part 2 dealt with the level of community well-being of the residents which give importance on the four aspects of community well-being provided in the barangay which are: healthy, safe, and inclusive community, culturally rich and vibrant community, dynamic resilient community and lastly, the sustainable and democratic environment. The questionnaire was based on Community Wellbeing Indicators developed by Alan Morton and Lorell Edwards (2012). A five-point Likert response rating scale is used (5 - 1), which includes Very High (5 points), High (4 points), Moderate (3 points), Low (2 points) and Very Low (1 point) respectively.

\section{Discussion of Result}

\subsection{Political Efficacy of the Residents}

Presented in Table 1 is the level of political efficacy of the residents in Davao City, Philippines with an overall mean of 3.58 which corresponds to a high descriptive equivalent indicating that the level of political efficacy of the residents in Davao City, Philippines was performed frequently or many times but not continuously done. The cited mean score was obtained from the result of the mean of the two (2) identified indicators of political efficacy that was specified in the given questionnaire appended in this study. The high level of political efficacy of the residents may attribute to the high rating of both indicators of political efficacy respectfully shown in table 1. Internal efficacy with a mean score of 3.57 
describe as high as well as external efficacy with a mean score of 3.58 also describe as high both contributed to the overall mean score which denotes to a high level of political efficacy of the residents.

Table 1. Level of Political Efficacy of the Residents

\begin{tabular}{lcc}
\hline Indicators & Mean & Description \\
\hline Internal Efficacy & 3.57 & High \\
External Efficacy & 3.58 & High \\
OVER-ALL & 3.58 & High \\
\hline
\end{tabular}

The high level of result shown in the study reflects that the residents in Davao City, Philippines often believe to their capacity to take part and affect their political system or society and further develop changes in it. It only implies that the level of political efficacy of the residents is high and it is frequently practice or even many times. Also, this manifests that the residents had a high political effectiveness and system responsiveness that denotes trust in one's ability to change or alter the system and trust in the capacity of the government to provide necessary improvements in the community as well as in promulgating what the residents wants as a citizen for the future development and synchronization of the public that are all often related to the identified indicators of political efficacy which are internal efficacy and external efficacy respectively.

In terms of internal efficacy, the high result obtain indicates the residents has a high perception about their impact in the political process as a result of their own skills and confidence. According to Grootel (2010), internal efficacy substantially requires knowledge which involves ensuring local politics, the individual sense of political competence and the ability to calculate the capabilities to act politically which involves self-qualification in politics, understanding politics, self-rating on public office, and being politically informed and active. In the same manner the subjective competence referring to the individuals' self-perception towards understanding and participating in politics effectively associated with political interest, knowledge and engagement (Sharoni, 2012; Hu, 2011; Xena, 2011). Consequently, internal political efficacy indicates that people or residents that often perceive themselves competent in understanding and participating in politics effectively are most likely based on how they think and know about their government, political environment as well as the actions they take similar with their involvement to the political spectrum. According to Grönlund, Setälä, and Herne (2010) that the subjective measure of an individual's evaluation of his or her own political competence and improvement of political knowledge and skills through a process of deliberation reflects an increase sense of internal efficacy.

On the other hand, external efficacy high rating obtained implies that the residents agree and believes to the local government unit had sufficiently provided and guaranteed their respective needs and demands in the community which reflects the residents high trust over the local government and believes in its capacity to provide necessary services for the development of the community. These findings support the idea of Sharoni (2012) and Zhao (2012) that external efficacy reflects the trust of the citizen to their government in achieving and providing their needs and demands. As such, high level of political efficacy somehow influences in return other political characteristics of a person most likely constitutes to political awareness and participation in the government as well as the actions done by the government in response to the needs of the society. According to Grootel (2010) that in external political efficacy the openness of the political system to the citizen's needs and demands is important that offers the citizens to an idea that the governmental authorities are interested in their demands and take their demands into consideration.

\subsection{Community Well-being of the Residents}

Shown in Table 2 is the level of community well-being of the residents of Davao City, Philippines with a descriptive equivalent of high which indicates that the activity was performed frequently or many times but not continuously done. It shows an overall mean of 3.68 which means that the level of community well-being of the residents in Davao City, Philippines was prominent but not at all times seen as adequately provided and given to the residents.

The overall mean was the result of the mean scores of 3.86 for healthy, safe and inclusive community; 3.53 for culturally rich and vibrant community; 3.64 for dynamic resilient community; and 3.67 for sustainable and democratic environment that all contributed to the overall mean score of community well-being with which all identified indicators obtained high descriptive equivalent.

Table 2. Level of Community Well-being of the Residents

\begin{tabular}{lcc}
\hline Indicators & Mean & Description \\
\hline Healthy, Safe and Inclusive Community & 3.86 & High \\
Culturally Rich and Vibrant Community & 3.53 & High \\
Dynamic resilient Community & 3.64 & High \\
Sustainable and Democratic Environment & 3.67 & High \\
OVER-ALL & 3.68 & High \\
\hline
\end{tabular}


The high level obtain for healthy, safe, and inclusive community denotes that residents in Davao City, Philippines felt safe and secure at all times in their respective communities and do not have any problem in terms of security around it. Also, residents imply that their respective community is a viable environment for children and young adults and appropriate for their respective development. According to Weaver, Born, and Whaley (2010) specific indicators related to how citizen feel about and fit into their community such as safety, social cohesion, and inclusion could be a means in measuring community well-being. In addition, a healthy community is a safe place and cities only achieve social sustainability when its citizen's basic needs are met thus, it become a fully inclusive community that refers to each person's participation and contribution are all welcomed, recognized, and valued (Annis, Racher, \& Beattie, 2008; Wachtel, 2008). This also post that the residents see their communities as an integrated and inclusive community which promotes basic services and facilities that expands positive development and security among their citizens which somehow summarizes the idea of various authors that community safety is one of the factors that influenced the citizens' participation in the community activity because the citizens put high regard on safety and it greatly affects the surroundings and the quality of life in the community. In addition, the said community safety addresses with various impact and harmful effects of crime and the ability of an individual to act and react from it (Sulaiman, Othman, Samah, Yero, D'Silva, \& Ortega, 2014; Idriss, Jendly, Karn, \& Mulone, 2010).

Another indicator describe as high is culturally rich and vibrant community, this indicator express the residents satisfaction towards the local government action to provide to the residents sports and recreational activities that helps develop themselves and also encourages them to develop their abilities and artistic and cultural diversity through activities that engage them to such domains apparently giving importance in making a diverse range of activity for the community that supports and provide not only the physical but social benefits for the residents. In this regard, it is congruent with the idea that a healthy community is one that is constantly creating and improving the physical and social environment of the citizen and expanding the resources found in the community in which people are able to mutually support each other in performing all the functions of life and developing their maximum potential (Perreault and Morrow, 2010). Thus, well-being based to various authors refers to different factors affecting their state of health, happiness and freedom reflected on their social, economic, environmental, cultural and political conditions which also help to further develop and flourish the full potential of the local community setting (Whaley, 2010; Wiseman and Brusher, 2014).

Meanwhile, dynamic resilient community also posts a high descriptive equivalent that denotes the residents' belief in their community to have a great deal of motivating factors such as job and economic development that changes and affects their way of life. This finding is congruent on the idea of Lucas (2012) that a person's life satisfaction in the community appears to have a great deal of motivating factor that influences the level of life satisfaction of a person. Factors such as income and wealth, availability and quality of jobs and work-life balance is a part of the community development and well-being of the citizen that should be provided and keenly examined by the local government to sustain the people's well-being that eventually creates a more productive and healthy society (Durand and Smith, 2013). Hence, economic diversity plays an essential role in community well-being and robustness in which contributes to community strength and resilience (Stubbs, 2009).

The last of community well-being indicator which also has a high descriptive equivalent is sustainable and democratic environment which means that the residents frequently perceives their local government as a community that provides basic needs of the citizens and put out opportunities for them to be heard and express their ideas for the development of their respective communities as well as engaging them to decision making process. This gives the readers an idea that local government act accordingly with its responsibility given by the higher authority and was delegated with task directly engaging with the citizen as part of the decentralization of the country's government. This idea support the viewpoint of Warner and Kern (2013) that in shaping the community well-being of local government should have the capacity to recognize and respond to the paramount and varied needs of its citizen. Government policy today has increasingly emphasized the need to involve community residents in decision making as well as informing them the community conditions and situations in the community social capital which is associated with health, low level of crime, educational achievement, and a strong sense of community relationship (Gilchrist, 2009). This highly reflects the idea of White (2011) that decentralization of government provides positive effects for decision making, finance, and administrative management of quasi-autonomous unit of local government.

\subsection{Correlation between Measures}

Table 3. Correlation between Measures

\begin{tabular}{ccccc}
\hline & Variables & r-value & p-value & Interpretation \\
\hline Political Efficacy & Community Well-being & .577 & .000 & Significant \\
\hline
\end{tabular}


Table 3 shows the test of relationship between variables which reveals that there is a significant relationship between political efficacy and community well-being of residents. The data denotes that political efficacy and community well-being with a total $r$-value of .577 and probability value of .000 has a significant relationship. This means that the feeling of an individual towards his or her political action affecting or creating an impact on the political process or system may somehow relied or affected by his or her idea of the community basic factions. This further implies that an individual state of being in the community can also be affected or related to the idea or perception of the individual toward his or her political action that affects the totality of the political system of a locality. Furthermore, this idea gives an understanding that political efficacy and community well-being mirrors each other. This finding is supported by Harris and Murphy (2012) that political efficacy reflects the overall well-being of the citizen and of the state. Results further imply that the null hypothesis of no significant relationship that was formulated and tested at $\alpha .05$ level of significance between political efficacy and community well-being is rejected.

\section{Conclusions}

The government as a focal edifice of governance should see to it that the well being of its constituents are in place. With respect to the findings of this study, it is concluded that political efficacy and community well-being of the residents is meaningfully high which manifest their high political effectiveness and system responsiveness in their community that further contributes to the effectiveness in their community conditions, that are often positive and be fitting to the advantage of their community. The results then revealed that there is a significant relationship between political efficacy and community well-being as identified through their corresponding indicators. It is then a clear manifestation that an individual's feeling towards his or her political action affecting or creating an impact on the political process or system may somehow rely or affected by his or her idea of the community basic factions and an individual state of being in the community can also be affected or related to the idea or perception of the individual towards his or her political action.

\section{Recommendations}

On the basis of the findings and conclusions of this study, the following recommendations are offered:

The respective barangays in Davao City should be provided with the results of the study for the feedback on the level of political efficacy and community well-being of the area. Such can be helpful in reference to creating new and improved plans and programs in the barangay to maintain the citizens' participation in the barangay level. It is a helpful instrument in determining the factors affecting the level of political efficacy and community well-being of the barangay. It can also be a basis of barangay policies promoting and achieving community well-being and political efficacy of the citizens.

The students of the University of Mindanao particularly the political science discipline should be provided with the result of the study to give them a range of information and perspective about political efficacy and community well-being to understand the importance of the two variables in understanding governance in the barangay level and how it affects the way of life of the people.

Similar study may be conducted in other places exploring other variables that affect political efficacy and community well-being in a larger scope of study.

\section{References}

Anderson, P., Cooper, C., Layard, R., Litchfield, P., \& Jane-Llopis, E. (2012).Well-being and Global Success. Retrieved July 8, 2014, from http://www3.weforum.org/docs/WEF_HE_GAC_WellbeingGlobalSuccess_Report_2012.pdf

Annis, R., Racher, F., \& Beattie, M. (2008).Rural Community Health and Well-being: A Guide to Action.Retrieved August 21, 2014 from http://www.brandonu.ca/rdi/files/2011/08/RuralCommunityHealth_and_Wellbeing_a_Guide_to_Action.pdf

Ddai, I., Opoku-agyeman, C., \& Ghartey, H. T. (2013).An exploratory study of religion and trust in ghana.Social Indicators Research, 110(3), 993-1012.doi:http://dx.doi.org/10.1007/s11205-011-9969-4

Durand, M., \& Smith, C. (2013).The OECD Better Life Initiative: How's Life? And the Measurement of Well-being. Retrieved July 21, 2014, from http://www.iariw.org/papers/2013/DurandPaper.pdf

Gilchrist, A. (2009). The Well-Connected Communities: A Networking Approach to Community Development. Retrieved August 25, 2014 from

http://books.google.com.ph/books?id=Tm5XMkUblskC\&dq=community++\%22well-being\%22\&lr=\&source=gbs _navlinks_s

Grönlund, K., Setälä, M., \& Herne, K. (2010). Deliberation and civic virtue: Lessons from a citizen deliberation experiment. European Political Science Review. 2(1), 95-117. doi:http://dx.doi.org/10.1017/S1755773909990245 
Grootel, L. (2010). Wavering respondent loyalties: Comparing three models of stability in political attitudes. Retrieved July 6, 2014 from http://essay.utwente.nl/61206/1/Grootel,_Leonie_E._van_-_S0064769_-_Master_Thesis_SSESR.pdf

Harris, C., \& Murphy, P. (2012).Assessing the Relationship between Community Education, Political Efficacy and Electoral Participation: A Case Study of the Asylum Seeking Community in Cork.Adult Learner: The Irish Journal of Adult and Community Education, 44, 58. Retrieved August 20, 2014 from http://files.eric.ed.gov/fulltext/EJ991816.pdf

Hu, X. (2011).The Effects of Political Participation on Political Efficacy: An Analysis of China's 2005 Survey on Self-Governance at the Village Level. Retrieved July 3, 2014, from

http://www.google.com.ph/url? sa=t\&rct=j\&q=\&esrc=s\&source=web\&cd=6\&cad=rja\&uact=8\&sqi=2\&ved=0CEo QFjAF\&url=http\%3A\%2F\%2Fcas.illinoisstate.edu \%2Fpol\%2Fconferences \%2F $2011 \% 2 \mathrm{FHu}$

Idriss, M., Jendly, M., Karn, J., \& Mulone, M. (2010). International Report Crime Prevention and Community Safety: Trends and Perspective. Retrieved July 21, 2014, from

http://www.crime-prevention-intl.org/fileadmin/user_upload/Publications/Crime_Prevention_and_Community_Saf ety_ANG.pdf

Ip, P., \& Cheung, Y. (2014). Probing folk happiness in Taiwan. Social Indicators Research, 117(3), 689-703. doi:http://dx.doi.org/10.1007/s11205-013-0393-9

Johnson, R. B., \& Christensen, L. B. (2000).Educational research: Quantitative and qualitative approaches. Boston: Allyn and Bacon.

Lucas, L. (2012). Theory and Validity of Life Satisfaction Scales. Retrieved July 4, 2014, from http://internal.psychology.illinois.edu/ ediener/Documents/Diener-Inglehart-Tay_Validity\%20of\%201s\%20measur es.pdf

Mangahas, M. (2014).Social weather in Davao City. Retrieved July 4, $2014 \quad$ from http://opinion.inquirer.net/74879/social-weather-in-davao-city

Morton, A., \& Edwards, L. (2012).Community Wellbeing Indicators Measures for local government. Retrieved July 20, 2014 ,

from

http://www.google.com.ph/url?sa=t\&rct=j\&q=\&esrc=s\&source=web\&cd=4\&cad=rja\&uact=8\&ved=0CDQQFjA

D\&url=http\%3A\%2F\%2Fwww.acelg.org.au\%2FdownloadUpdate.php\%3FdocId\%3D206\&ei=mh_NU_yDAdfao

ATT9IHIDw\&usg=AFQjCNGIHqYgZZNBIkw34ODUnty1WASZ6A\&bvm=bv.71198958,d.cGU

O’Donnell, G., Deaton, A., Durand, M., Halpern, D., \& Layard, R. (2014). Wellbeing and Policy. Retrieved July 4, 2014, from

http://li.com/docs/default-source/commission-on-wellbeing-and-policy/commission-on-wellbeing-and-policy-repor t---march-2014-pdf-.pdf?sfvrsn=5

Perreault, L., \& Morrow, L. (2010).The 2009 Community Well-being Report. Retrieved August 21, 2014 from http://www.weareunited.com/img/pdfs/annual-reports/2009wellbeingreport.pdf

Sharoni, C. (2012). e-Citizenship: Trust in Government, Political Efficacy, and Political Participation in the Internet Era. Retrieved July 5, 2014, from http://www.emandp.com/site_content_uploads/main_content/sharoni.pdf

Stubbs, J., Lux, c., Storer, J., \& Flinn, J. (2009).Measuring Community Wellbeing in 'Cotton Communities': The Socio-Economic Impact of the Australian Cotton Industry on Selected Regional Communities. Retrieved August 20 , 2014

from http://www.google.com.ph/url?sa=t\&rct=j\&q=\&esrc=s\&source=web\&cd=1\&cad=rja\&uact=8\&ved=0CB8QFjAA \&url=http\%3A\%2F\%2Fwww.cottoncrc.org.au\%2Ffiles\%2Fec303816-a1aa-4c7d-ba3f

Sulaiman, A. H., Othman, J., Samah, B. A., Yero, A., D'Silva, J. L., \& Ortega, A. (2014).Determinants of community participation in community policing program in Malaysia. Journal of Applied Sciences, 14(20), 2439-2449. Retrieved from http://search.proquest.com/docview/1545972882?accountid=31259

Ubalde, C. (2012). Senate resolution prods official measure of Filipino happiness. Retrieved July 5, 2014, from http://www.interaksyon.com/business/21697/senate-resolution-prods-official-measure-of-filipino-happiness

Virola, R. (2010). What Makes Women Happy. Retrieved July 8, 2014, from http://www.nscb.gov.ph/headlines/StatsSpeak/2010/110810_rav_joe_happiness.asp

Virola, R., Encarnacion, J., Pascasio, M., \& Clavido, R. (2010). Measuring Progress of Philippine Society: What Makes the Poor Happy? Retrieved July 8, 2014, from 
http://www.nscb.gov.ph/ncs/11thNCS/papers/invited\%20papers/ips-23/01_Measuring\%20Progress\%20of\%20Phili ppine\%20Society\%20What\%20Makes\%20the\%20Poor\%20Happy.pdf

Wachtel, A. (2004). Welcoming and Inclusive Communities and Workplaces Program. Retrieved August 21, 2014 from http://www.welcomebc.ca/welcome_bc/media/Media-Gallery/docs/service/programs/welcome_program/pdf/resear ch_framework.pdf

Warner, K., \& Kern, M. (2013).A City of Wellbeing. Retrieved July 21, 2014, from http://www.smgov.net/uploadedFiles/Wellbeing/wbp-Research-whitepaper-FINAL.pdf

Weaver, L., Born, P., \& Whaley, D. (2010). Approaches to Measuring: Community Change Indicators. Retrieved August 25, 2014 from http://tamarackcci.ca/files/measuring_community_change.pdf

Whaley, D. (2010). Approaches to Measuring More Vibrant Communities. Retrieved July 22, 2014, from http://tamarackcommunity.ca/downloads/vc/Measuring_More_Vibrant_Communities.pdf

White, S. (2009). Bringing Wellbeing into Development Practice. Retrieved July 6, 2014, from http://www.welldev.org.uk/wed-new/workingpapers/workingpapers/WeDWP_09_50.pdf

White, S. (2011). Government Decentralization in the $21^{\text {st }}$ Century: A Literature Review. Retrieved September 22, 2014, from http://csis.org/files/publication/120329_White_Decentralization_Web.pdf

Wiseman, J., \& Brasher, K. (2014). What is Community Well-being. Retrieved August 25, 2014 from http://www.takingcharge.csh.umn.edu/enhance-your-wellbeing/community/what-community-wellbeing

Zhou, Y., \& Pinkleton, B. E. (2012). Modelling the effects of political information source use and online expression on young adults' political efficacy. Mass Communication \& Society, 15(6), 813. Retrieved from http://search.proquest.com/docview/1196326231? accountid=31259

\section{$($ (c) $)$ EY}

This work is licensed under a Creative Commons Attribution 3.0 License. 